Peer-Reviewed Article

ISSN: 2162-3104 Print/ ISSN: 2166-3750 Online Volume 7, Issue 4 (2017), pp. 1048-1064 (C) Journal of International Students http://jistudents.org/ doi: 10.5281/zenodo. 1035963

\title{
The Role of Student Affairs in a New University in a Conflict Zone
}

\author{
Enakshi Sengupta \\ The American University of Kurdistan, Iraq
}

\begin{abstract}
Higher education necessitates an understanding that students cannot be confined to the classroom, as a large part of their curriculum comprises extracurricular activities to educate intellectually, in spirit, and body. AS a result, community building, advising, and career development became a part of the traditional routine of student affairs. This article explores the role of student affairs in a newly formed university in a conflict zone ravaged by war and terrorism for decades. The data explored in this article reveals some interesting facts, which are different from that of the traditional student affairs manager. In this university, student affairs personnel are viewed as a 'job giver,' someone who will arrange funds, bursaries, and scholarships in keeping with the war-ravaged economic scenario of the province in northern Iraq.
\end{abstract}

Keywords: advising, extracurricular activities, funding, guidance, integrity, induction, scholarship

Students do not begin or end their journey of acquiring knowledge only in the premise of its classroom bounded within four walls. A greater part of their learning is interwoven throughout the duration of their study enhanced by their college experience-from the very first day of orientation and 
admission to the last day of receiving their diploma in hand. Students are enrolled in a higher education institution hailing from various backgrounds and even nationalities. They are inducted into the institution with their preconceived notions and stereotyping, which may be shaped or altered by their college experiences. Tinto (1993) postulates that students first must separate from the group with which they were formerly associated and to which they belonged from early childhood, such as family members, neighbors, and school peers, and then undergo a period of transition. In this period of transition, the students begin to interact in new ways with the members of the new group into which they seek to have membership (Tinto, 1993), and it is only then that they can incorporate or adopt the normative values and behaviors of the new group or college as it shall be explored in this article discussing the role of a student affairs manager helping students in this transition.

This study explores the role of the student affairs department in a newly formed university in a conflict zone ravaged by war and terrorism for decades. The American University of Kurdistan came into being in 2014 amidst war torn Iraq, destruction of economy, and the terror attacks from Daeesh, and home-grown violence. The current building, which houses approximately 300 students, became operational in August 2015, having a low key inaugural function only in March 2016, in an effort to avoid attraction from the so called Islamic State which is 40 kilometers away from where the university has been built. The governorate of Duhok, where the university is situated, has suffered setback in its economy having lost Mosul, once a gateway to the export import market and tourism, to ISIS. Jobs are harder to find and the problems with Iraq have left the coffers of the Kurdistan regional government dry, making it harder to even pay salaries to government officials (Coles, 2014)

This study is written in the thick of economic crisis and severe security concerns. Every element of life has undergone a new meaning in this part of the world and survival is the most elemental instinct from which young students are not spared. Students expect the student affairs department to help them find jobs, bursaries, or at least a work-study program. The traditional role of student affairs is found to have crumbled, as they are not viewed as a facilitator of co-curricular activities but more as a financial aid officer.

In the wake of this given scenario, the author seeks to answer two pertinent questions through this study: 
1. How does the traditional role of student affairs affect the development of a student affairs department serving a new institution within a conflict zone?

2. What roles should student affairs departments play based on the geopolitical and socio-economic conditions of a country operating in a conflict zone setting?

\section{LITERATURE REVIEW}

Studies have been conducted on the effects of organizational behavior on students. Berger (2000) found that different patterns of organizational behavior do influence outcomes in various ways for different students. His findings are supported by the study of Clark, Heist, McConnell, and Yonge (1972) who argued that campuses exert a more powerful impact on student outcomes when colleges are found to have clear visions that are articulated through congruent and consistent sets of policies, procedures, traditions, and espousal of values in their daily operations.

In a broad sense, the college environment encompasses everything that happens to a student during the years of study in an educational institution. The environment consists of the programs, personnel, curricula, teaching practices, and facilities that become a part of any educational program and even the racial and institutional climate in which the program operates (Astin, 1991). For a student attending a college, apart from pedagogical techniques of the professors, the physical surroundings, behavior of the classmates, the peer groups, and the co-curricular activities in which the students participate are important components of their environment. The task of assessing the environment involves identification and quantification of these external circumstances and events that the students have been exposed to in college.

Schlossberg's (1984) transition theory provides insight into factors that are related to the individual, the environment in which they thrive, and the transitions that they undergo. It also deals with the nature of support that is available to the student at a particular time. Schlossberg addressed the nature of support needed to facilitate coping and strategies required to assist those experiencing the change (Evans, Forney, Guido, Patton, \& Renn, 2010). Schlossberg, Waters, and Goodman (1995) found that if students feel good about the transition and believe it is happening at an appropriate time, it will be easier for them to make the transition. However, if students feel transitions are being forced upon them and they are unhappy about having to 
attend school, their transition will be more difficult. Schlossberg et al. (1995) proposed four factors that have an impact on a person's ability to cope with transition and result in optimal integration with a racially diverse group of students. These four factors are Situation, Self, Support, and Strategies, commonly known as the 4 S's. Support is defined by Schlossberg et al. (1995) as "the key to handling stress" (p. 67). Evans, Forney and Guido-DiBrito (1998) described the types of support that adults need as "affect, affirmation, aid, and honest feedback" (p. 114). This support can come from a variety of sources, including "intimate relationships, family units, networks of friends, and institutions and communities" (Evans et al., 1998, p. 114). This article highlights the support of a student affairs department and the expectation of the students from the manager of this department.

Students are supported in their development through various staff members who work as academic advisors, helping students select majors and build their class schedules. There are residential life staff who supervise the students' living conditions in the dormitories or in residence halls. The admissions officers help students decide on the courses they are to be enrolled in and career counselors assist students with finding the right internships and the right careers after their graduation that will help fit their talents and aspirations. Faculty members and staff help develop students' cognitive and interpersonal skills, foster leadership, ethics, and cultural understanding. Throughout the college journey, students are supported by a breadth of people who help them grow and gain learning experiences predominantly outside of the classroom.

One of the main domains of such support staff are those who work as student affairs professionals. This area of work has a long history and role in higher education and, over the years, has been called student personnel, student services, student development, and other names (Long, 2012). The purpose of this study is to investigate whether the traditional role of a student affairs manager has undergone any transformation in the context of the university being situated in a conflict zone. The author considers questions such as who are student affairs managers and what are the core functions that comprise student affairs departments at colleges and universities? What are the core values and policies that guide their work? What are the emerging trends and issues that are transforming student affairs today? Do socio-political and geographical factors have any influence in shaping the work of student affairs departments and should they confine themselves to routine work as expected of them or go out of their way to 
incorporate unprecedented factors that shape the lives of students in or outside the campus? This study answers these questions with an overview of the history, values, essential competencies, functions, and new directions for the field of student affairs.

\section{INSTITUTIONAL CONTEXT: THE AMERICAN UNIVERSITY OF KURDISTAN}

Established in 2014, the American University Kurdistan (AUK) seeks to foster respect for learning, knowledge and genuine academic achievement. Located in the heart of Duhok, in northern Iraq, AUK strives to become a leading center of academic excellence and research. The university aims to mold the next generation of leaders through challenging courses, up-to-date methodology, and qualified, experienced faculty members (About AUK, n.d.). The university is relatively new and the inauguration of the main building was conducted in the fall of 2015. The total number of students at present is only 300, mostly enrolled in the first-year English Language Institute. The university will eventually comprise six colleges including Business, Arts \& Sciences, Engineering, International Studies, Health Sciences, and Education.

The university is committed to shaping leaders for local and regional communities by offering quality education, research, and careeroriented programs. The university aims to become a prominent academic and research hub in this region and practice the highest standards of intellectual integrity and scholarship. The mission of the university, as outlined by the Chairman, His Excellency Masrour Barzani, is to create a passion for promoting education and blending intellectual substance and social action. AUK will have its own distinctive approach that offers the highest level of education in a vibrant community in Kurdistan. The student-faculty relationship works to create life-long relationships and career networks, which will have a positive impact on academic achievement, career performance, and students' lifetime achievements (Letter from the Chairman, 2017).

\section{The American University of Kurdistan: Students Affairs Department}

Mission. The Student Affairs mission is to enhance student development and achieve academic success by having facilities, programs, 
and services dedicated to support AUK student needs in a friendly, confidential and helpful manner every step of the way.

The mission of the department is to identify and respond to students needs and to create and foster a safe, healthy, diverse, and attractive campus environment. The mission also advocates respecting and empowering students by giving them their own voice as well as updating knowledge and skills in order to continuously support students at the highest level. The mission of the department also promises to establish and cultivate a positive and healthy relationship among students at the highest level while providing outstanding student-centric personal growth and equip students for the job market.

The vision of the department is to strive for engagement among AUK students, to foster an inclusive, dynamic, and innovative community. The student affairs department stands for core values such as integrity, which aims to contribute to a respectful, pleasant, healthy, and ethical environment. It promises to support students and show genuine concern for health, well-being, balance, and academic success. It strives towards excellence in its commitment to deliver and provide excellent support and advice through continuous improvement of the center and professional development of the staff. The department respects diversity and embraces values in terms of different ethnicities, religions, and ideas. Learning remains its top most agenda and its values gaining and acquiring knowledge and developing necessary life and academic skills needed in order to be successful. (Handbook of Students Affairs, 2017)

Area of work. The Office of Student Affairs (OSA) is engaged in collaborating with AUK students, faculty, and staff. The OSA provides a wide range of programs, services and support for fostering students' intellectual and personal growth. The Office of Student Affairs includes Advice and Guidance; Counseling, Health, and Wellness; Campus Life; Accommodation and Transportation; Athletics; and Career Services.

Advice and Guidance helps students reach their educational and career goals by providing them advice and guidance on academic related issues during their studies at AUK. Academic Advising at AUK is based on the belief that advising is a developmental process, recognizing such logical and sequential steps as the exploration of life goals and career goals. This process of exploring, integrating, and synthesizing should be an ongoing and multifaceted responsibility of both the students and the advisors, the ultimate goal of which is student growth. Through such a student-centered 
approach, general and major advisors assist students in creating a personally relevant plan for educational, career, and life fulfillment.

The Counseling, Health, and Wellness section helps AUK students identify and talk about personal, social, and study problems which can interfere in achieving academic success. This service is solely for undergraduate students enrolled at the AUK. Counseling, Health, and Wellness offers students the opportunity to talk about their problems and concerns in private. After listening to the student, the counselor helps to provide practical solutions to difficult issues. A variety of issues and concerns are dealt with (i.e., stress, anxiety, anger, depression, violence, etc.). In addition, this section provides students with physical and mental care as well as personal wellness education, and holds workshops on personal wellness, including antiviolence education, drug/alcohol addiction and prevention, and nutrition. AUK has a Health Clinic available in the basement of the university building for minor injuries and initial consultation including 24-hour ambulance services for emergencies.

Campus life further extends the Student Affairs mission in fostering a warm and welcoming campus community by providing services and student life programs. Students have the opportunity to participate in student activities and events as well as engage in community service. The Student Government leadership program gives students an opportunity to have a voice of their own. This student body, which represents all students, is called the Student Government. It voices and addresses the students' needs, wants, and concerns to the university administration. Furthermore, the Student Government has been set up to promote student participation and involvement in clubs and other organizations, to organize social, cultural, and academic activities, and /or programs and to provide assistance and support for the activities and programs sponsored by the Office of Student Affairs. Community service is a service provided by AUK students assisting the community and society voluntarily. Both the community and the students will benefit from this experience. The community will be provided assistance and support and students, on the other hand, will develop leadership skills and explore service career options. Several programs will be set up with institutions that desperately need assistance and support. The community support service is crucial to Kurdistan with the influx of millions of internally displaced people (IDP) escaping from Mosul to Duhok and other neighboring areas and migration of Syrian refugees to Kurdistan. AUK, along with other local nonprofit organizations strive to provide support to the refugee camps. 
AUK plans to be a residential university with two residence halls for men and two for women. The halls will be located on the AUK campus and close to the academic halls and sport centers for extracurricular activities. The Office of Student Affairs also offers student transportation at several occasions. AUK plans to have its fixed route bus services both inside and outside of Duhok. The buses will run on an abbreviated schedule and will not run during holidays. Transportation at present is being provided for field trips and other outside engagements.

AUK offers its students a wide range of sports and recreational programs. The Athletics section is responsible for keeping the AUK community engaged and healthy by providing a wide range of sports such as hockey, football, soccer, tennis, athletics, and an internal sports facility. The mission of this program is to provide engagement, excitement, competition, and fun to all participants in a diverse, relaxed, and structured environment. Sports Activities AUK provides a recreational sports program for participation in a wide variety of sports and recreational activities for the academic community. The activities represent a broad selection of sports ranging from those of a highly competitive structured nature to informal social activities. A variety of programs are offered including intramural sports, fitness, and wellness classes, informal recreational activities, sport clubs, and special events. For all sporting activities, clubs must abide by the policies and procedures governed by the Health and Safety Guidance for AUK Sports club handbook

AUK aims to increase the level of employability among AUK graduates and alumni, to build lasting connections with the private, public, and NGO sectors, and to coordinate with AUK faculties and departments to align curricula with market needs.

\section{RESEARCH METHOD}

In order to answer the two research questions raised in this study, the author adopted a mixed method study in designing the research, combining both quantitative and qualitative research methods in different ways, where both the distinctive approaches contribute towards the understanding of the phenomenon. It was felt that mixing the methods would offer a better understanding of the research problem than any other design would. Hall and Howard (2008) call this approach a synergistic approach, which combines two or more options so that their combined effect is greater than the sum of the individual parts. When translated into mixed methods, this 
means that the sum of quantitative and qualitative research is greater than either approach alone.

\section{Quantitative Method}

There was a need to study the experience of students while dealing with the student affairs department and especially their role towards managing students in a conflict zone. Studying such phenomena requires choosing an approach that allows generalizability of findings, highlighting the findings that are specific to a particular context, and conducting the research objectively. This can be done by implementing a quantitative method of study (Sengupta, 2015).

The quantitative methodology used in this study required fieldwork, which helped the researcher to grapple with the general climate of the student body at the institution. A quantitative method was used to quantify opinions, attitudes, and behavior in order to find out how students feel about the role of the student affairs department (Sukamolson, 2011).

Designing the questionnaire. The questions were kept short and simple and were phrased in language that is easily understood by students. Phrases that can be ambiguous or have double meanings were avoided. Questions that may pre-determine a respondent's answer as well as questions that contain stereotypes or emotionally superlative words were also avoided. Care was taken not to frame questions that would be misleading, or imply unstated assumptions and to avoid leading questions, which imply a desired response. Questions were re-read and revised to avoid putting respondents on the defensive or generating hostility or suspicion. The questionnaire was explained to the respondents before administering it so that the participants had all the necessary information to complete the questions.

Generation and analysis of data. The participants were chosen randomly, the only criteria being that they were presently enrolled as students at AUK. The university being new has a limited number of students, around 300. 116 students were asked to complete the survey form. The ratio of female students to men is quite negligible. In a class of 30 there may be 3 or 4 female students, hence judging the responses based on gender was not a viable option. Since the university has just began its operation almost all the students are in their first year of study, barring 4 senior students, segregating them by year of study had no implication to the study. 
Students were chosen randomly and their response recorded by a survey questionnaire.

Participants. A total 116 students were surveyed. Out of 116 students, 63 students belonged to the English Language Institute (ELI) and were studying English. The ELI course takes one year to complete, which means all 63 students were in their first year. Out of the remaining 43 students, five students were the most senior and are from the College of Business. Twelve students belonged to the first year of the undergraduate program and hailed from the College of International studies and only four students belonged to the College of Computer Technology. The remaining 22 students also belonged to the College of Business and were in their first year of undergraduate coursework. The ratio of female to male students is very negligible in this university and from a total of 116 participants, only 11 of them are female students. Students are mainly Kurdish; some of they have been repatriated belonging to the Kurdish diaspora in Holland and Sweden. Some students are of Arab origin, Yezidi, or Assyrian Christians, but their numbers are very insignificant when compared to the Kurdish students.

\section{Qualitative Method}

The author used qualitative method with the rationale that "the use of quantitative and qualitative approaches in combination provides a better understanding of research problems than either approach alone" (Creswell \& Plano Clark, 2003, p.5). This is based on the logic that "one cannot separate methods from the larger process of research of which it is a part" (Tashakkori \& Creswell 2007, p.304). The semi-structured questions designed by the researcher allowed participants to respond freely and extensively about the topic, only to be steered back to the right path if they happened to deviate. Qualitative interviews were conducted with three focus groups of students. Focus group A had five senior students, who will be the first group of students to graduate from this university and have been enrolled since 2014, giving them considerable time to interact and know about all the departments in the university. Focus Groups B and C were comprised of seven and six students respectively. They belonged to the first year of their study but had already spent six to seven months at the university and therefore had the chance to interact with the student affairs department and to take part in events organized by the student affairs department. The analysis began using Nvivo software with detailed coding 
and conceptualization either through line-by-line coding or at times by applying a general approach. The author started identifying or examining the underlying ideas, assumptions, and conceptualizations shaping the data (Braun \& Clarke, 2006).

\section{FINDINGS}

Awareness of Student Affairs Department: Students were asked whether they are aware of the existence of the student affairs department. 90 students $(n=90)$ answered in the affirmative, while $n=26$ answered that they are not aware of such a department. The data shows that the majority of the students have heard about the department.

Interaction with the Manager of Student Affairs: Students were further asked whether they have interacted with the manager of student affairs at least once in their tenure of study. While 62 students out of the 116 surveyed answered in the affirmative, 54 students chose "no." Thus, almost $50 \%$ of the total participants did not have the chance to interact with the student affairs manager or even if they had, they are not aware of his designation or role as the manager of the department. This clearly states that the manager (currently the head of the department) requires more visibility and needs to familiarize himself with the students. Perhaps this can be done with a well-planned orientation program that welcomes the new students or any event that involves the students.

Event that led to interaction: Students were asked whether they remember the event or the incident that led them to interact with the student affairs department for the first time. Forty students $(n=40)$ out of the total 116 participants answered that they had interacted with the student affairs department while acting as a volunteer in an event, which is only $34 \%$ of the students. This finding is supported by the focus group interviews, in which students voiced their disapproval stating "they only call us to become the volunteer, we are never involved in any event from the beginning" (Student A, Focus Group 1). Twenty students stated that they interacted with the department while inquiring about the student handbook or seeking clarification on the information stated in the handbook. Only seven students out of 116 participants interacted with the department while expressing their desire to participate in the university election. Forty-three students $(n=43)$ did not interact even once with the department. Again the number is quite significant, nearly $37 \%$ of the total participants did not have any interaction with the department. 
Frequency of interaction: Students were asked as to how many times they have interacted with the student affairs department in the past. The number of students that have "never" participated in interacting with the department is 42 , nearly $37 \%$. Twenty-six students have interacted occasionally, 16 students have interacted once a month, 24 students once a week and only eight students interacted with them on a daily basis, aligning with our earlier data of seven students who wanted to participate in the university election. It is possible that these are the elected student representatives who need to communicate with the department on a daily basis.

Role of the department: Students were asked about the role of the department, which they feel should be the area of work for the department. Sixty-two students, nearly half the participants $(53 \%)$, felt that the role of the department ought to be "holding all students to high expectation for engagement and learning, in and out of class, on and off campus." Thirty-six students answered that their job should be "invest in program and people that demonstrate contributions to students learning and success" and 18 students felt that the department should work towards "sustained commitment to achieving the institution's educational mission." This data was further re-affirmed with the themes derived from the qualitative data finding that the role should be to provide students with "more involvement to acquire experience."

Role of the department in a conflict zone: The very last question on the survey questionnaire dealt with the role of the student affairs department working especially in a conflict zone. Sixty-eight students, or $58 \%$, believed that the department should "facilitate job opportunities for students in need." The university is established in the northern part of war-ravaged Iraq. The Kurdistan regional government has seen a draining of its wealth due to an ongoing oil crisis, ISIS threats, and war to combat terrorism. The cities have witnessed in recent times an influx of refugees from Syria and internally displaced people like the Yezidi population and people fleeing ISIS from Mosul. Some of the students are wards of Martyr's and prisoners of war. Most of them had family members participating in the war as "Peshmergas" (i.e., the military forces of the autonomous region of Iraqi Kurdistan) or they themselves have participated in the war before enrolling as a student in the university. Economic crisis looms large and seeking a job after graduation or developing a source of stipend or income is a priority for the students. This question also resulted in 28 students wanting the student affairs department to "facilitate scholarships and other educational loans for 
those who in need." Twenty students wanted the department to "organize charitable work in the refugee camps," so that the students could volunteer in such programs and help those who are in a dire state in the camps.

The questionnaire ended with an open-ended question asking for additional comments. Nearly $96 \%$ of the students refrained from commenting. Only a few voiced that "they have promised financial aid since two years, they are not giving jobs to people in need" (Student B, Survey Questionnaire). Two students also commented on the integration issue among the students, as there are Kurdish students, Arab students, Yezidi students and students from the Kurdish diaspora from Holland and America studying in the university. Their comments read, "students affairs to be honest is doing nothing to engage students with each other and how to spend time together in the university, it should help students to interact with each other...."(Student C \& D, Survey Questionnaire).

\section{Themes}

Three themes emerged from the focus group interviews answering the research question on the role of the student affairs department in general and that in a conflict zone. The first theme was "more involvement." Students expressed their opinion that they felt they were not adequately involved in the events organized by the student affairs department. They felt they are only used as volunteers, "They only call us at the end, just to become volunteers, they never involve us in the conceptualization of the events" (Student E, Focus Group A). Another student expressed,

They should at least talk to us once, maybe the student government, we can help them in designing some meaningful events mainly charitable work with the NGOs in refugee camps. We are used to just handout articles collected for the refugees. We want to feel that we are also a part of the event and not there to take merely take orders. (Student G, Focus Group A)

The second theme that emerged out of the qualitative interviews conducted from three focus groups was "we don't need to be told." Students objected to the fact that most of the time the student affairs department is found sermonizing about the do's and don'ts about Kurdish culture, especially mixing with female students and group formation. Some of them expressed their anger stating,

We are Kurdish too, we know about our culture. They don't need to tell us all the time what we should be doing and what we shouldn't. 
That is not a part of their job. They are not qualified sociologists or even counselors. (Student H, Focus Group B)

Similarly, one participant stated, "I think instead of telling us about talking to girls and what we should be do, they should help us in undertaking more extracurricular programs", (Student I, Focus Group C).

The third theme that was the strongest of all the themes was "creating job opportunities and financial aid." Most of the students spoke about the student affairs department helping students to find a part-time job while they are studying or sponsorship which would provide financial aid to the students. This theme was in keeping with the quantitative finding where the majority of the participants voiced that the department should help them in finding jobs. The socioeconomic condition of Iraq including that of Kurdistan had suffered a setback since the days of Saddam Hussein and further worsened by never ending conflict and civil war. The condition was aggravated by the inflow of the so-called Islamic state, which took over the prime cities of Mosul, thus affecting trade with other countries. The city of Duhok has witnessed millions of migrant populations from neighboring Syria and the towns occupied by ISIS in its refugee camps. The situation has not been able to show any sign of recovery due to the fall in oil prices, thus putting a further strain in the coffer of the regional government. Students and their families too have felt the weakening of economy and hence seeking jobs has become their priority. Students are looking for avenues to earn money and they would want the student affairs department to help them in their quest.

\section{ANALYSIS OF DATA}

The quantitative data showed that half of the student population who was surveyed $(n=116)$ have never interacted with the student affairs department or have never met the manager. Drawing from the literature review and Schlossberg's (1984) concept of "support" that the students look for during their transition from school life into a college environment, the data demonstrates that this seems to be lacking to an extent. The students were unable to establish the bond with the student affairs department due to their lack of visibility or not involving the students in the events crafted by them.

Only $34 \%$ of survey participants have worked with the manager as a volunteer for an event. Students in the interviews have expressed their desire to be more involved with the department as was evident from the qualitative interviews where students spoke about, "they only call us at the end, just to 
become volunteers, they never involve us in the conceptualization of the events." The students are eager to be a part of the department and conceptualize or implement an event and not merely act as a volunteer or as an usher, "we can help them in designing some meaningful events mainly charitable work with the NGOs in refugee camps." Clark et al. (1972) argued that campuses exert a more powerful impact on student outcomes and that outcomes can be built by exposing the students to co-curricular activities and involving them in decision making events. Astin (1991) also spoke about creating a positive environment for the students during their transition into a college life. The environment consists of the programs, personnel, curricula, teaching practices, and facilities that become a part of any educational program. The student affairs manager has a great contribution in shaping the environment. The quantitative data also shows that $58 \%$ of the students are eager to seek jobs or some kind of financial aid and wants the manager of student affairs to liaison with the external partners and link them to such opportunities. Similarly, the qualitative data suggests "they should find us some opportunities or involve us in the university as trainees where we can earn some money" (Student J, Qualitative Interview Focus Group 1). The qualitative interviews echoed the same sentiment as is narrated in the last theme of the interviews. The open-ended question in the survey questionnaire also saw some students voicing their discontent of not having given adequate opportunities to work either in the university or in the outside world and earn money as their stipend.

\section{CONCLUSION}

Student affairs departments cannot only restrict themselves to their traditional roles if their underlying value is to care for the students. "Care is a fundamental value that student affairs professionals strive to instill in students. This generally takes the form of service learning, as students learn to understand the situations of others and want to advocate on their behalf" (Long, 2012, p. 8). Roberts (2003), a leading expert in community development, characterized community as the binding together of individuals toward a common cause or experience. Building a sense of community between students has a myriad of educational benefits, which includes the development of leadership skills, instilling empathy and responsibility, and conflict resolution.

In most cases, student affairs professionals are not trained or licensed counselors, but the experience of handling students teaches them 
helping skills because of their direct contact with students. Helping skills may not at all times address a student's emotional well-being, but to provide the student with coping skills and with the context for making decisions that solve his or her own dilemmas. Counseling and helping skills increase a student affairs professional's capacity to create positive relationships and environments for students. The student affairs department at The University of Kurdistan may not be in a position to solve the financial needs of each and every student but the helping skills will create positive regard for each other, empathy and a caring culture in the university. Positive and constructive advice will help the students to cope with their current needs and choose options towards the betterment of their future. This is important as "core values such as caring, helping, equality, and social justice inform much of the environments that student affairs professionals strive to create as the best conditions for student learning and success" (Long, 2012 p. 35).

\section{REFERENCES}

Astin, A. W. (1993). Diversity and multiculturalism on the campus: How are students affected? Change: The Magazine of Higher Learning, 25(2), 4449.

Astin, A. W., \& Sax, L. J. (1998). How undergraduates are affected by service participation. Journal of College Student Development, 39(3), 251-263.

Berger, J. B. (2000). Optimizing capital, social reproduction, and undergraduate persistence. In J. Braxton (Ed.) Reworking the student departure puzzle (pp. 95 -124), Nashville, TN: Vanderbilt University Press,.

Braun V, \& Clarke, V. (2006). Using thematic analysis in psychology. Qualitative Research in Psychology 3(2), 77 - 101.

Coles, I. (2014, March 17). Iraq funding cuts spark salary crisis in Kurdistan, test limits of their autonomy. Ekurd Daily. Retrieved from http://ekurd.net/mismas/articles/misc2014/3/state7837.htm .

Clark, B. R. Heist, T. R. McConnell, M. A. \& Yonge, T. G. (1972). Students and college: Interaction and change. Berkley, CA: Centre for Research and Development in Higher Education.

Creswell, J. W., \& Plano Clark, V. L. (2003). Designing and conducting mixed methods research. Thousand Oaks, CA: Sage.

Evans, N. Forney D. S., Guido F. M., Patton, L. D. \& Renn K. A. (2010) Student development in college: Theory, research, and practice. $\left(2^{\text {nd }} e d.\right)$. San Francisco, CA: Jossey-Bass.

Evans, N. Forney D. S., \& Guido-DiBrito, F. (1998). Student development in college: Theory, research, and practice. San Francisco, CA: Jossey-Bass. 
Long, D. (2012). The foundations of student affairs: A guide to the profession. In L. J. Hinchliffe \& M. A. Wong (Eds.), Environments for student growth and development: Librarians and student affairs in collaboration (pp. 1-39). Chicago, IL: Association of College \& Research Libraries.

Nuss, E.M. (2003). The development of student affairs. In S.R. Komives, D.B. Woodard Jr. \& Associates (Eds.). Student services: A handbook for the profession. $\left(4^{\text {th }}\right.$ ed., pp. 65-88). San Francisco, CA: Jossey-Bass.

Roberts, D. C. (2003). Community building and programming. In S. R. Komives D.B. Woodard Jr. \& Associates (Eds.). Student services: A handbook for the profession (4th ed., pp. 539-554). San Francisco, CA: Jossey-Bass.

Schlossberg, N. K. (1984). Counseling adults in transition: Linking practice with theory. New York, NY: Springer Publishing.

Schlossberg, N. K., Waters, E. B., \& Goodman, J. (1995). Counseling adults in transition (2nd ed.). New York, NY: Springer.

Sengupta, E. (2015). Integration in an International University in Malaysia. (Unpublished doctoral dissertation) University of Nottingham, Malaysia.

Sukamolson, S. (2011). Fundamentals of quantitative research. Bangkok, Thailand: Chulalongkorn University.

Tashakkori, A., \& Creswell, J. W. (2007). The new era of mixed methods. Journal of Mixed Methods Research 1(3), 3-7.

The American University of Kurdistan, Students Handbook. The American University of Kurdistan. Retrieved from www.audk.edu.krd,

Tinto, V. (1993). Leaving college: Rethinking the causes and cures of student attrition. (2nd ed.). Chicago, IL: University of Chicago Press.

ENAKSHI SENGUPTA, PhD, is the Dean in the College of Business at the American University of Kurdistan, Iraq. Her research interests include corporate social responsibility; business ethics; higher education; student integration; curriculum; inclusiveness in education; refugee education; internationalization of higher education; and student mobility. Email: Enakshi.sengupta@auk.edu.krd 